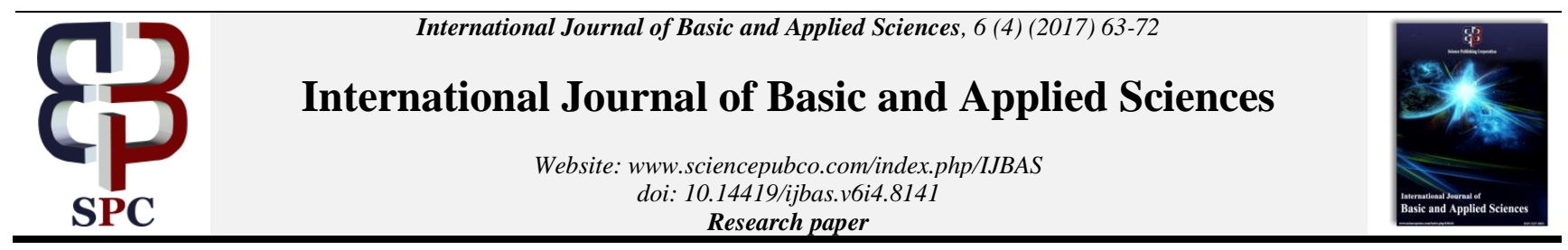

\title{
New cubism \& Picasso to inspired interior design and furniture
}

\author{
Asmaa Abdel Gawad El Sebaey* \\ Associate Professor, Interior design and furniture Department, Faculty of Applied Arts, Helwan University \\ *Corresponding author E-mail: asmaelsebaey@hotmail.com
}

\begin{abstract}
Pablo Ruiz Picasso is one of the best documented and one of the most influential artists of the twentieth century. During his life, he created more than 20,000 paintings and sculptures. Through his invention of forms and techniques, his exploration of space, and his experimentation, Picasso was the leader of an artistic revolution that reached not only painters and sculptors, but also authors, composers, and architects. Picasso begins to look at nature in terms of shapes like cones, spheres and cylinders. It was Picasso's literal translation of this advice that led to one of his most influential periods, a period characterized by an exploration of space and form called Cubism.

The aim of this study is to analyze Picasso's paintings as an entry point to get in the interior design. Additionally, try to create new design methodology that inspired by Cubism.

The current research discusses what is the cubism? What is the relationship between cubism and modern architecture? I focus in my paper at the Cubism's concepts, technical and stylistic aspects. Also, I explain Picasso's career beginnings, African-influenced period and his crystal period.

Objectives:
\end{abstract}

1) Analytical study for the philosophical concept of Picasso's paintings and Cubism, from an architectural viewpoint.

2) Inspired design methodology from Picasso's paintings and Cubism to be used in furniture design and internal spaces.

Keywords: Pablo Ruiz Picasso - Cubism - Modern Architecture.

\section{Introduction}

In the chronological history of art, there are periods, which are more positive, more complete than others. This means that there are periods in which there are better artists than in others. If the history of art could be graphically represented, as in a chart used by a nurse to mark the changes of temperature of her patient, the same silhouettes of mountains would be shown; proving that in art, there is no ascendant progress, but that it follows certain ups and downs that might occur at any time. The same occurs with the work of an individual artist. Many think that cubism is an art of transition, an experiment which is to bring ulterior results. Those who think that way had not understood it. Cubism is not either a seed or a foetus, but an art dealing primarily with forms, and when a form is realized it is there to live its own life. A mineral substance, having geometric formation, is not made so for transitory purposes, it is to remain what it is and will always have its own form. However, if we are to apply the law of evolution and transformation to art, then we have to admit that all art is transitory. On the contrary, art does not enter these philosophic absolutisms . Mathematics, trigonometry, chemistry, psychoanalysis, music and what-not, have been related to cubism to give it an easier interpretation. All this has been pure literature, not to say nonsense, which has only succeeded in blinding people with theories. [1]
From the painters of the origins, the primitive, whose work is obviously different from nature, believed in painting nature as it is. And from the point of view of art, there are no concrete or abstract forms, but only forms, which are more or less convincing lies. That those lies are necessary to our mental selves is beyond any doubt, as it is through them that we form our aesthetic point of view of life. [2] Because of the emergence of new technologies like photography, the motor car, cinematography, and the airplane, artists felt the need for a more radical approach; a new perspective that would expand the possibilities of art like the new technologies was extending the limits of communication and travel. This new perspective was called Cubism, also known as the first abstract style of modern art. [3]

\subsection{When and where appeared the Cubism movement?}

In Paris six years before First World War, Louis Vauxcelles pioneered the cubism, that he named George Braque's artworks in 1908 at l'Estaque because his paintings looked like some cubes. Cubism is a new vision for a new century that inspired paintings that were initially ridiculed by critics for consisting of "little cubes." [4] Example: fig. 1.

\section{Cubism movement}

\subsection{What is cubism}



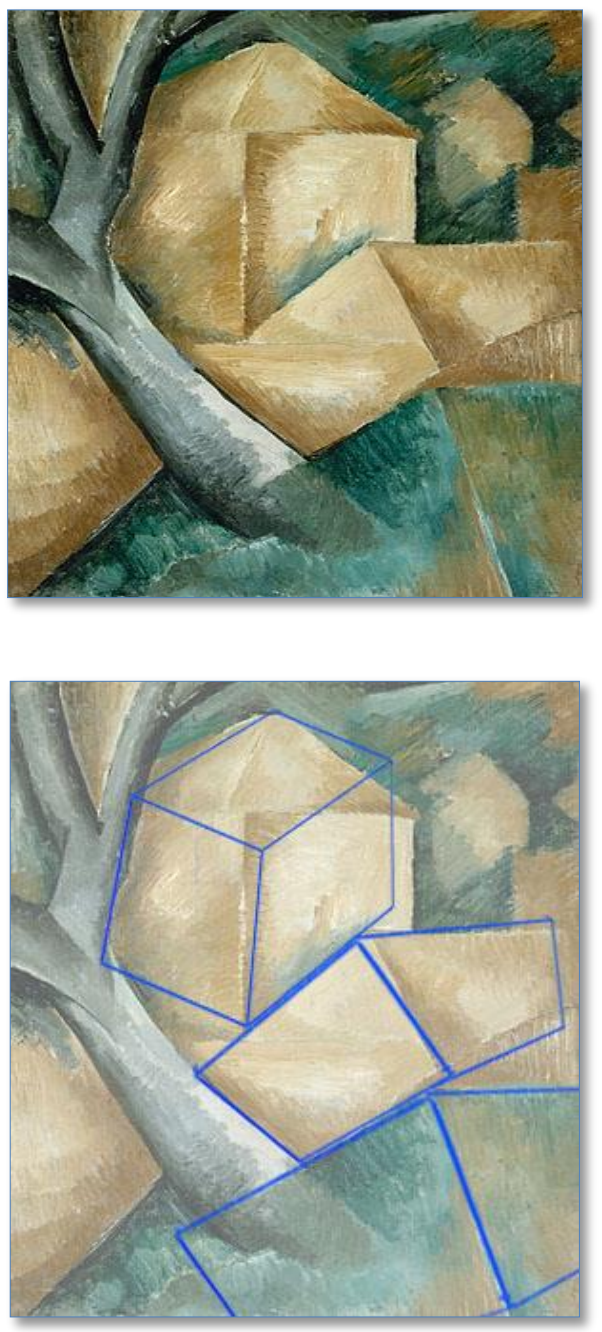

Fig. 1: Houses at l'Estaque, by George Braque, Oil on Canvas, $40.5 \mathrm{Cm}$ $\times 32.5 \mathrm{Cm}, 1908$.

Pablo Picasso and Georges Braque invented cubism, that it is considered as a revolutionary new approach to representing reality. Picasso and Braque aimed to bring different views of figures together in the same picture, to make a new system of re-arrange signs on the surface of canvas. Cubism along with the De Stijlists in Holland, Futurists, Dadaists, Constructivists and Supremacists in Russia - represented the next generation and one with an altogether more radical notion of the new. They elevated mechanical perfection over craftsmanship and sought to eliminate subjectivism from art. Traditional artistic representations, limited to more or less casually selected fragments of the material world, as seen through an individual's senses and personality. [5]

\subsection{Different opinions regarding when cubism began}

Some described Cubism, that it reflects human's normal thoughts expression about nature. And others said that cubism just be a new approach, although others pointed out, cubism resisted natural standards.

\subsection{Phases of cubism}

In the development of Cubism, there were three phases: Facet or Pre-Cubism, Analytic Cubism, and Synthetic Cubism, although some divide the movement only in Analytic and Synthetic Cubism. [3] Example: fig. 2.

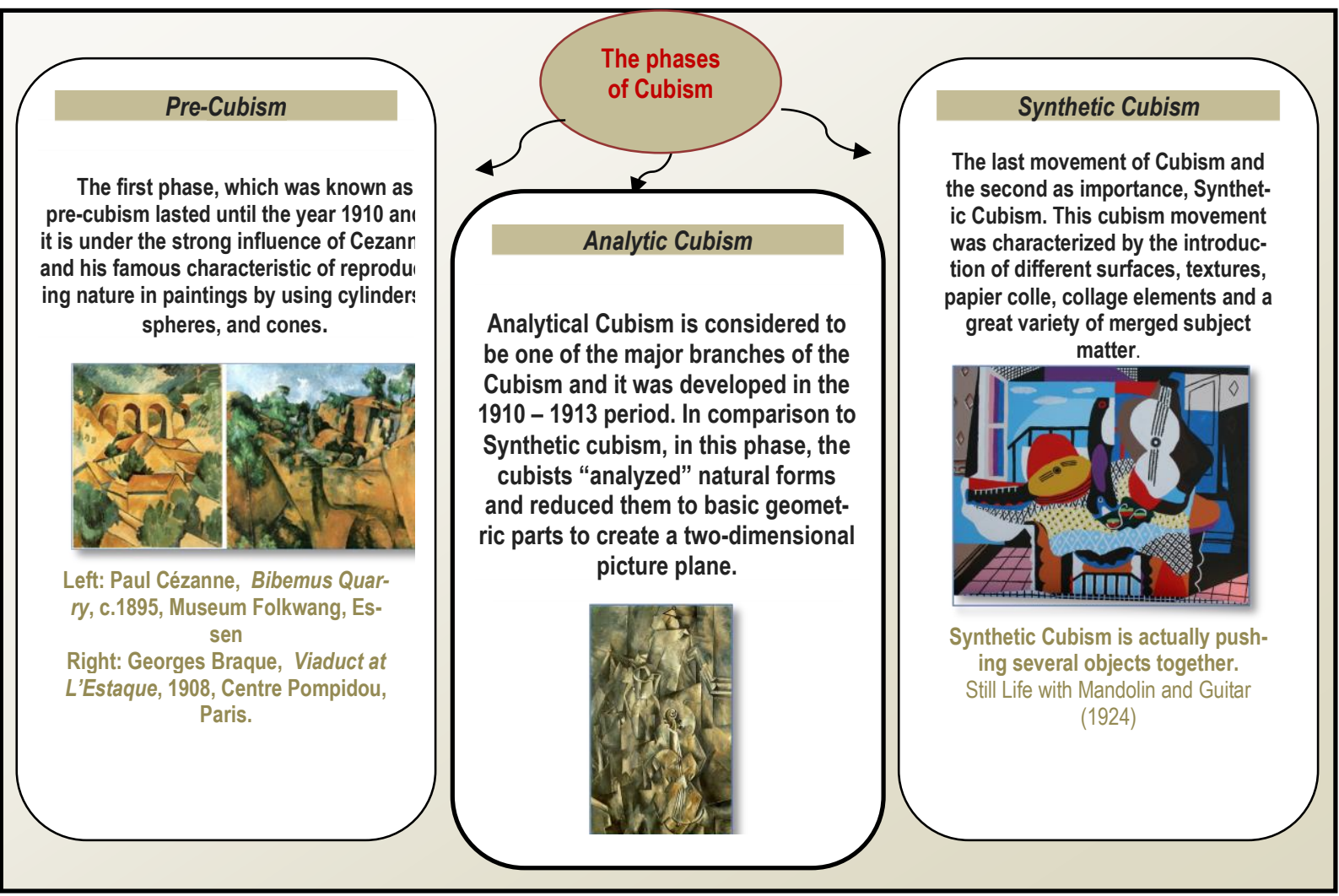

Fig. 2: Phases of Cubism. 


\subsection{The Cubist vision}

Picasso's comments on Cubism were given in an interview with an American critic, in 1923. They are skeptical about attempts to intellectualize representing it instead as an art like any other whose success. [2] Cubist were conceived some own concepts, formed them together to be rounding out the vistas.

1) Cubism must followed scientific discovery, to be like science that displays all hidden of nature.

2) Cubist released appearances thought, and built on sense of what's behind objects and complete it by their way.

3) Picture in Cubism maybe overlook objects come up through observation of the physical images, to form mental images as a reflection of the thinking process.

4) Thinking gives honesty for cubism project, that for expresses the idea of subject, rather than describe it in personal way.

5) Cubist artworks provided art with supplies to see nature in: pluralism, generalized, movable and static, instead of being fixed and especially.

6) When you look at an object your eye scans it, stopping to register on a certain detail before moving on to the next point of interest and so on. You can also change your viewpoint in relation to the object allowing you to look at it from above, below or from the side. [6] Example: fig. 3, 4.

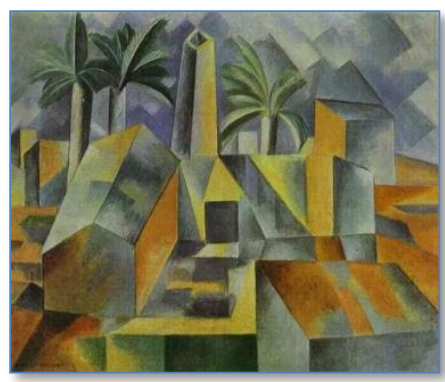

Fig. 3: Left: Factory, Horta De Ebbo, by Pablo Picasso, 1909. Cubist Seeks to Reproduce Different Perspectives Simultaneously like They Might Be Seen by the Mind's Eye.

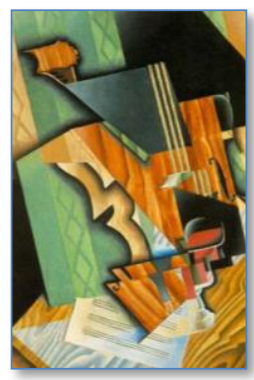

Fig. 4: Right: 'Violin and Glass' by Juan Gris, 1915.

1) The Cubist painters rejected the inherited concept that art should copy nature, or that they should adopt the traditional techniques of perspective, modeling, and foreshortening. They wanted instead to emphasize the two-dimensionality of the canvas.[3] Example: fig. 5, 6.

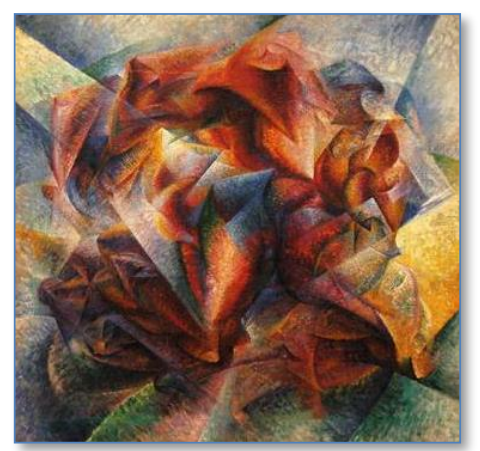

Fig. 5: Left: Dynamism of A Soccer Player by Umberto Boccioni, 1913. in This Work, A Soccer Player Dematerializes Into A Luminous and Flickering Atmosphere, Save for His Firmly Sculpted Calf, at the Center. Here Boccioni Offered A Demonstration of A Principle He Articulated in His Technical Manifesto of Futurist Painting.

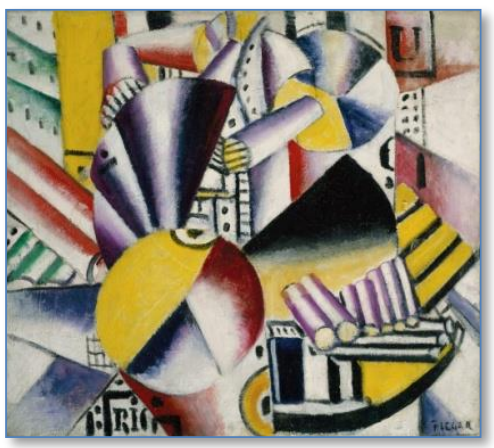

Fig. 6: Right: the Bargeman by Fernand Leger, 1919. Leger. Simplified the Forms in His Pictures Into Geometric Components of the Cone, Cube, and Sphere, Leaving Their Contours Unbroken. He was Also Fascinated by Machines and Modern Technology.

\subsection{Cubism in architecture $\&$ design}

Some people might say that the relationship between Cubism and architecture was at best tentative and it involved the application of Cubist decorations to stripped neoclassical buildings. However, in Prague, the Czech Cubist group (Chochol, Gocar, Capek, Hofman, Janak and Novotny) managed to do more than treat the facades with prismatic ornaments.

The basic features of Cubism, however, which included asymmetrical compositions, transparency, inter penetration of volumes and simultaneous perception from different points of view were enshrined in the Modern Movement and played an important part in its evolution. [3]

The most representative feature of cubist architecture was the multi-faceted facade of a building, which was also a way of articulating a vision of space, especially the relation between inside and outside. In other words, the cubist design should not celebrate the solid tectonic qualities of the material but to call those into question, establishing an ambiguous relationship between the space on the inside and on the outside of the structure. [3]

- The House of the Black Madonna Example: fig. 7, 8, 8 . 


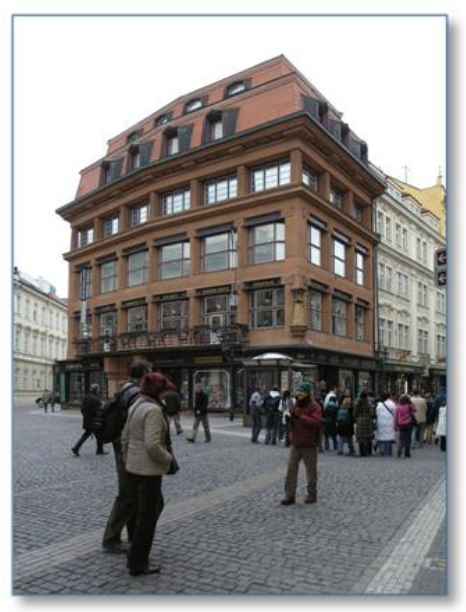

Fig. 7: Left: the House of the Black Madonna Is A Cubist Building in The "Old Town" Area of Prague, Czech Republic. It was designed by Josef Gočár. It Is Currently in Use as the Czech Museum of Cubism.

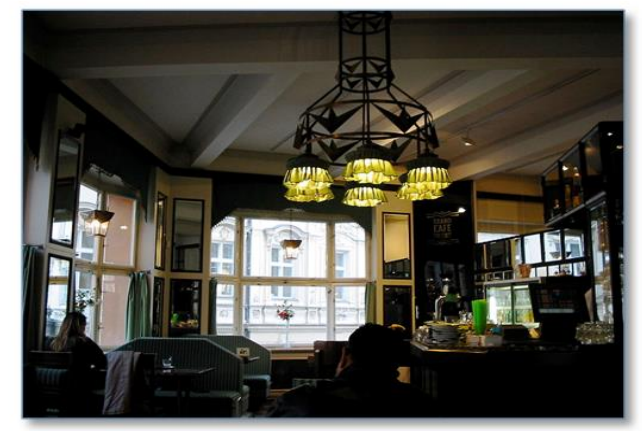

Fig. 8: Middle: The Grand Café Orient Restaurant on the First Floor.

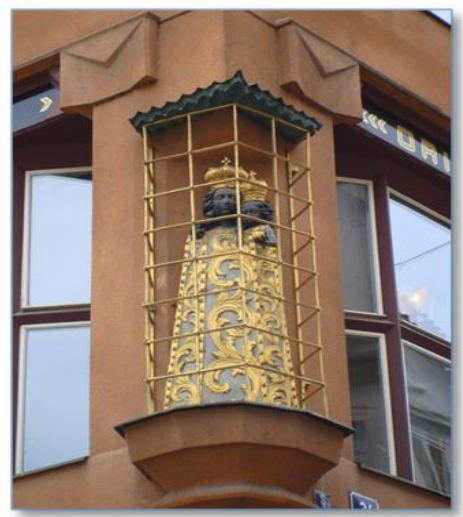

Fig. 9: Right: Figure of House Elevation.

- Gemelli Design Studio

Cubism design By Gemelli Design Studio is reminiscent of the cubism art movement pioneered by Pablo Picasso, with cool colors and quirky abstract lines. Example: fig. 10, 11, 12.
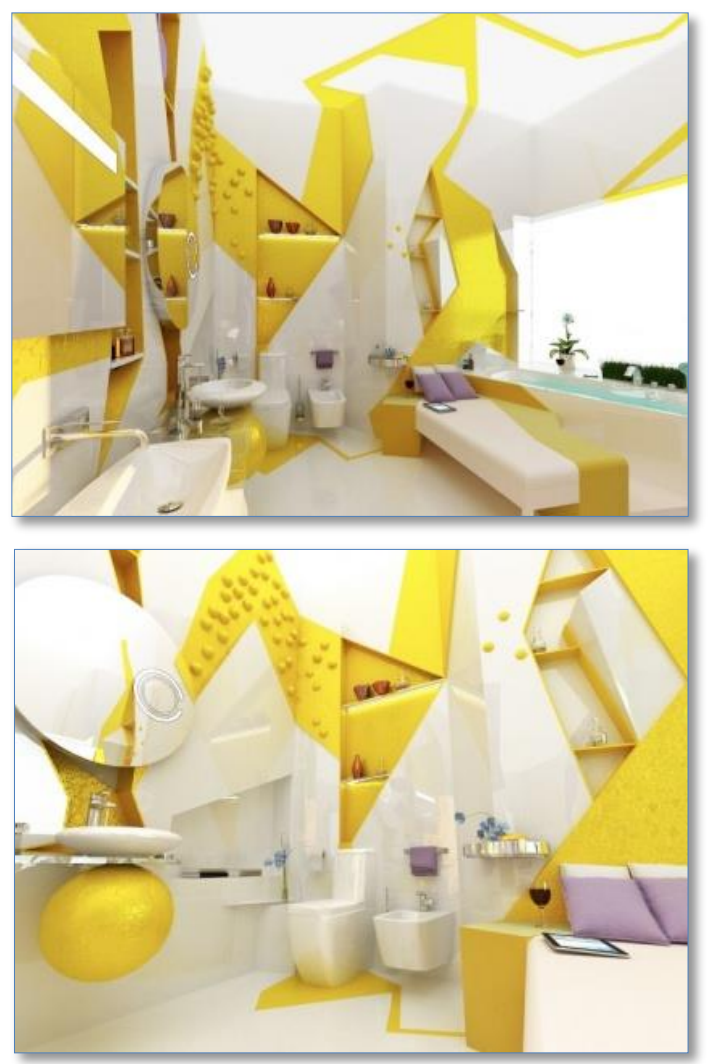

Fig. 10: The Unique Look Is Definitely A Refreshing Change from the Usual Safe Neutral Palette and Plain Walls.
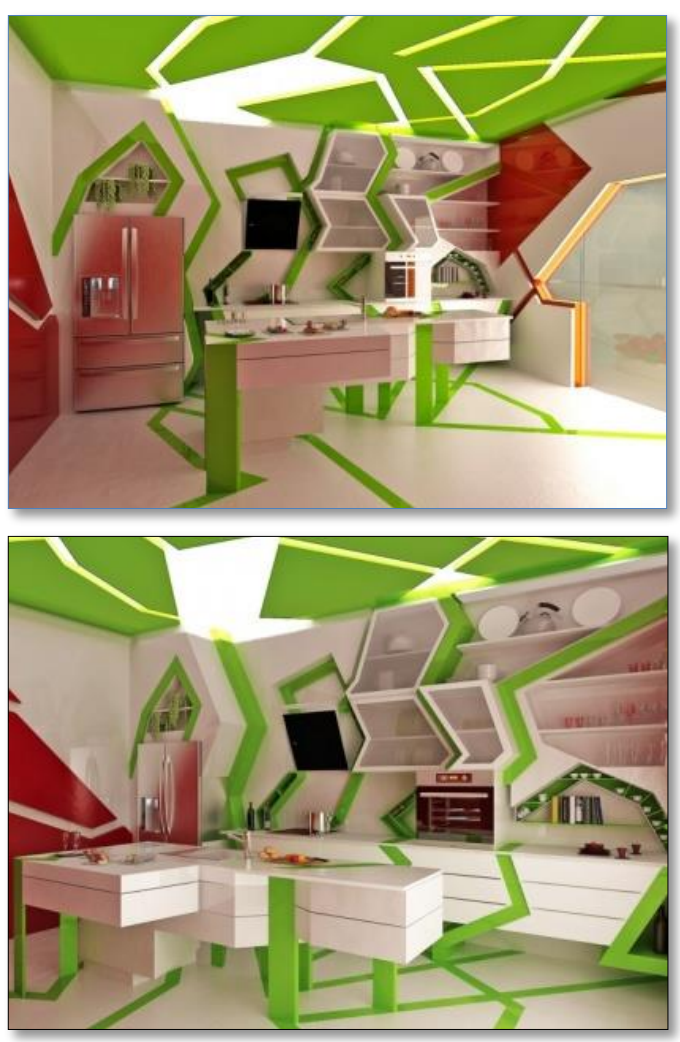

Fig. 11: This Wild Kitchen Has Stationery Green Laser Beams. 


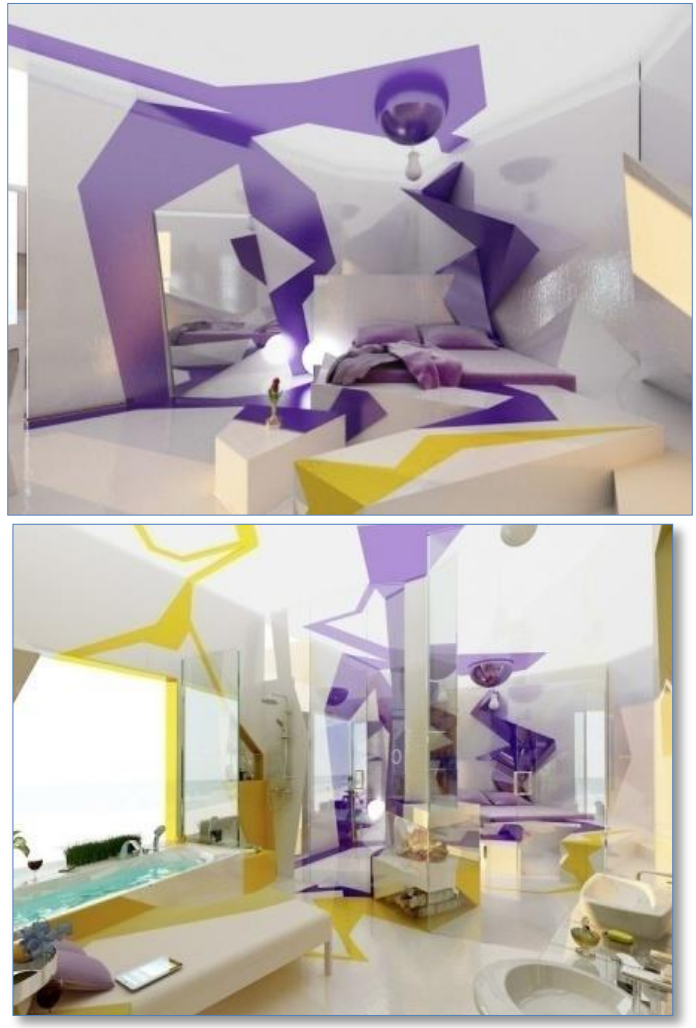

Fig. 12: The Complication of Angles Cleverly Throws Off All Dimensions Too, Adding Interest, and Dividing Even the Smallest Space Into A Maze of Zones, Which Makes A Tiny Room Appear Bigger by Distracting the Eye from the Real Proportions.

- $\quad$ New York home. Example: fig. 13.
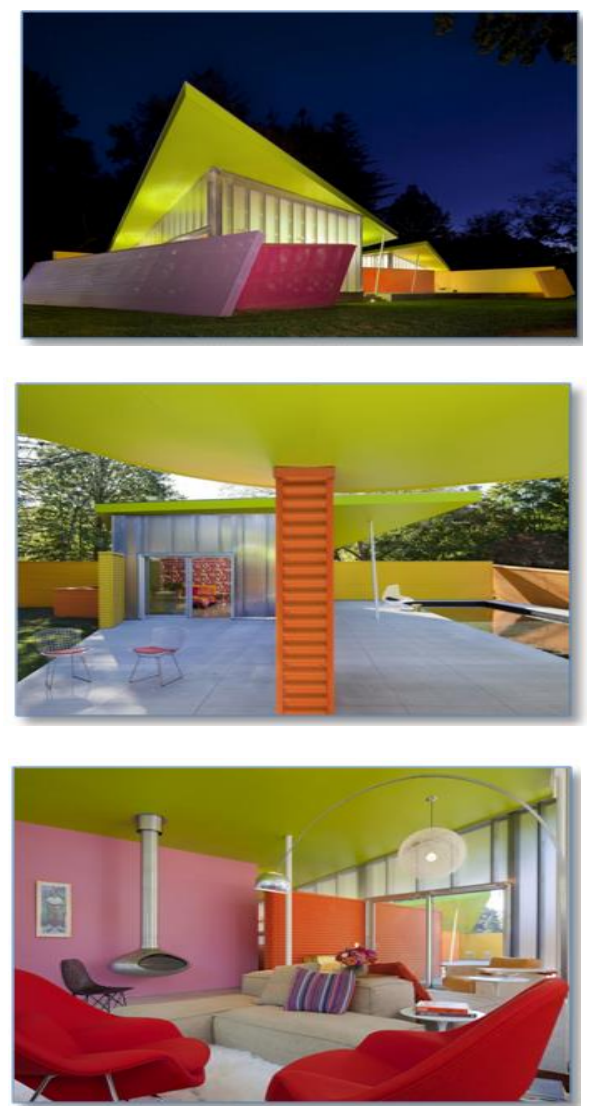

Fig. 13: This Showy New York Home Designed by Stamberg Aferiat + Associates Looks More Like an Art Installation than A House. The Illuminated Abode Is A Contemporary Cubist Sculpture Boasting Twisted Skewed Roofs and Translucent Walls that Glow Eerily from Within.

\section{Pablo ruiz picasso}

One of the most influential artists of the twentieth century is Pablo Picasso and his conception of revolutionary new figurative styles revolutionized the world of modern art. Throughout his career, he sought inspiration from a variety of artistic styles, a search that was ignited by his early interest in the medieval art and heritage of Catalonia.

\subsection{Biography}

Pablo Picasso was an expatriate painter, sculptor, printmaker, ceramicist and stage designer, born on October 25th, 1881 in Malaga, Spain. Picasso is one of the most influential artists of the 20th century. He has huge collections of famous artworks including Three Musicians, The Three Dancers and Self Portrait: Yo Picasso. Picasso died on April 8th, 1973 in Mougins, France. [7].

\subsection{Factors provided Pablo Ruiz Picasso's career}

- How Picasso's childhood affected his paintings.

Pablo Ruiz Picasso's influence was profound and far-reaching for most of his life. Picasso was born into a creative family. His father was a painter, and he quickly showed signs of following the same path, and his father would be his first teacher. Picasso began formally studying art at the age of eleven. Several paintings from his teenage years still exist. His father cared the young prodigy to be a great artist by getting Picasso the best education the family could afford, visiting Madrid to see works by Spanish old masters.[8] Picasso fond of bullfighting, as he attended with his father since his childhood to watch those performances, influenced by the bulls a lot, and bullfighting was the first Picasso oil paintings on wood. [9]

\subsection{Impact of Paul Cézanne at Picasso's work}

Influenced by Paul Cézanne from 1907 to 1909, that Picasso used a combination between realistic and geometric represented by human and nature. [9]

Cézanne's insistence on redoing nature according to a system of basic forms was important to Picasso's own interest at that time. In Cézanne's paintings, Picasso found a model of how to distill the essential from nature in order to achieve a cohesive surface that expressed the artist's singular vision. Beginning in 1907, Picasso began to experiment with Cézanne's techniques alongside fellow artist Georges Braque. Cézanne was a constant touchstone for the two artists during this period of collaboration, which eventually resulted in the invention of Cubism by 1909. Throughout Picasso's stylistic evolution over the next seven decades, he continued to borrow from and reinterpret Cézanne's art. [10] Refer to: tab. 1.

Table 1: Impact of Paul Cézanne at Picasso's Work

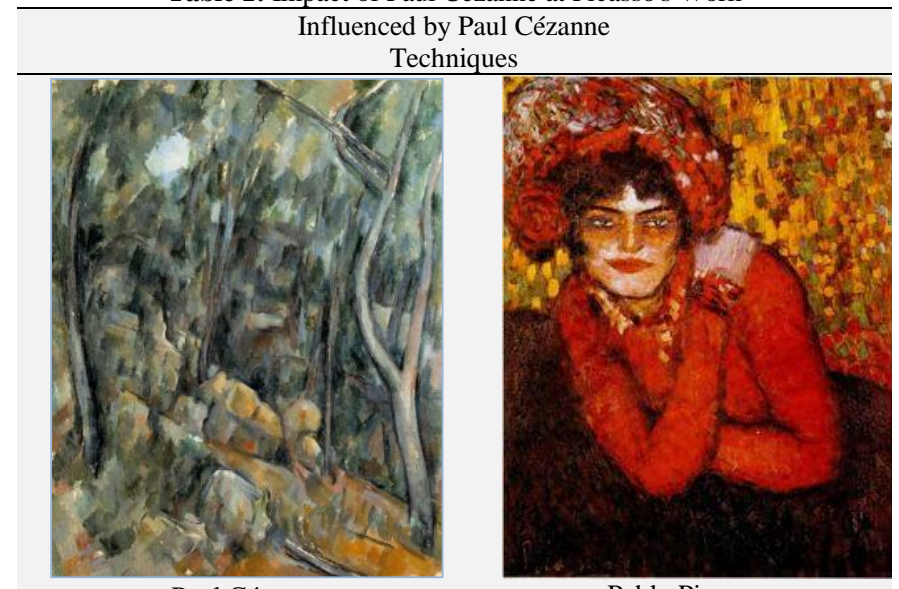

Paul Cézanne

The Grounds of the Château Noir c. $1900-6$
Pablo Picasso

Pierreuse la main sur l'épaule, 1901 
Using lots of repeated brush strokes and lots of small flat shapes (or planes). Paintings also often seem to be painted from different viewpoints so you can see. Showing things from different angles he was able to show that they were three-dimensional.

\section{Inspiration}

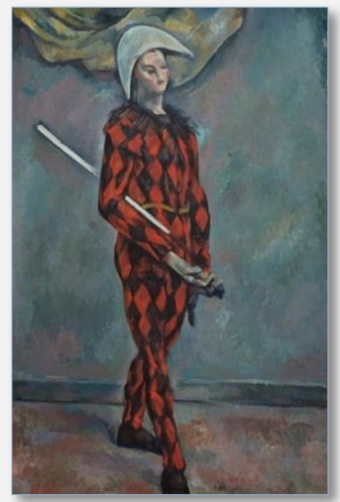

Paul Cézanne

Harlequin, 1888-90, oil on canvas, National Gallery of Art.

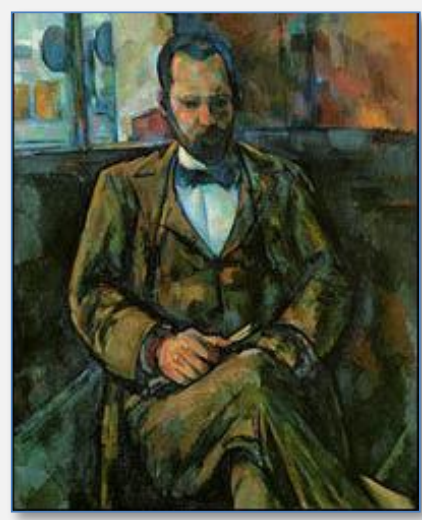

Ambroise Vollard, 1899, by Paul Cezanne. Vollard made his mark as a dealer in 1895 with his Cezanne show, which brought the painter out of obscurity.

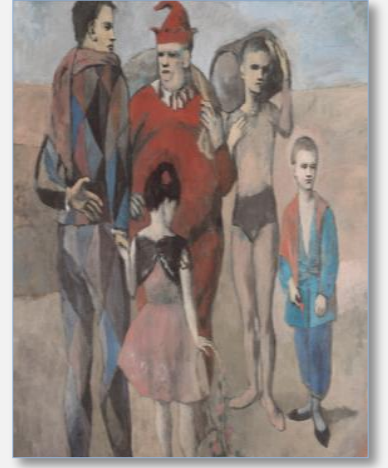

Pablo Picasso Family of Saltimbanques, 1905, oil on canvas, National Gallery of Art.

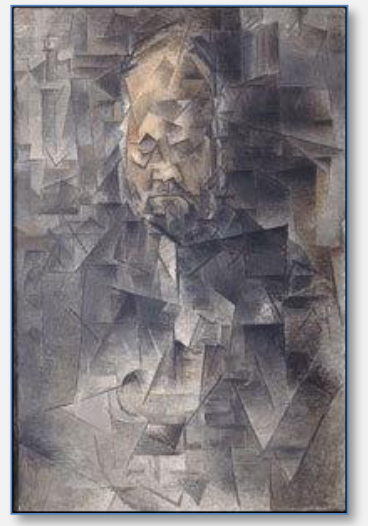

Ambroise Vollard, 1910, by Pablo Picasso. Picasso had his first solo show in Paris at Vollard's gallery. It's also where that artist saw Paul Cezanne's influential work.

\subsection{Impact of women at Picasso's painting}

Women was an important factor at art life of his long-standing, from time to time, he was accompanied by one or more, that reflected clearly at his paintings. All of Picasso's women affected differently at his artistic productions, because they were an inspiration of his paintings.

Picasso changed his art style during every woman he knew, for example; Madeleine was inspired him to the blue stage, Fernand influenced him to Rosary phase and the beginning of Cubism, either Olga made Picasso to return to the classic. Also his first wife Olga who was a Russian ballerina and the second wife Jacqueline inspired Picasso as long as last twenty years until he died.

Picasso's was a creative and women lover but he was a tough, Picasso drew a lot of nude women including his lover MarieTherese. Refer to: tab. 2
Table 2: Impact of Women at Picasso's Work

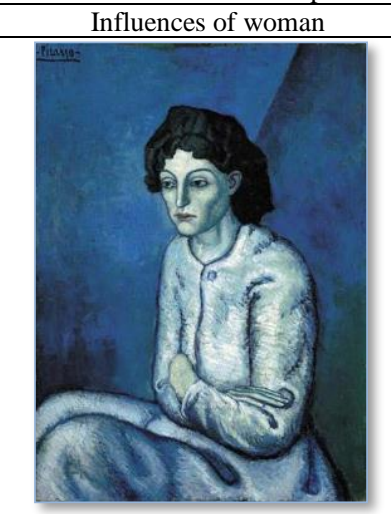

Pablo Picasso, 1901-02, Femme aux Bras Croisés (Woman with Folded Arms)

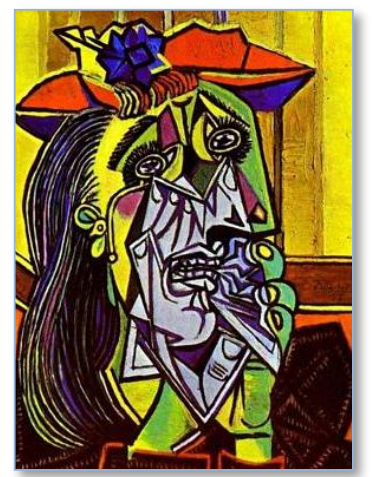

Weeping Women, 1937 Oil on canvas

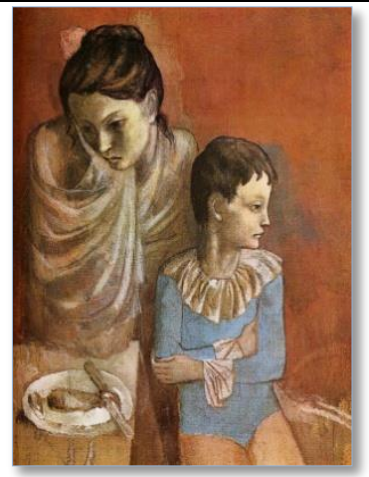

Pablo Picasso, 1904-05, Les Baladins (Mother and Child, Acrobats),

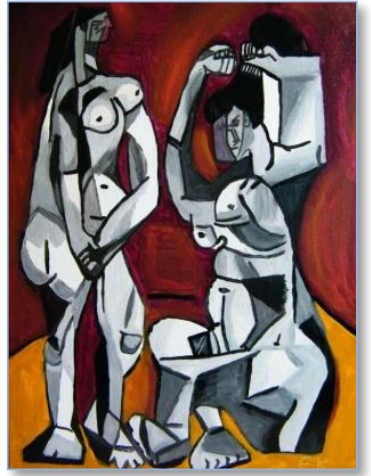

Women at the toilette, 1956 Painting of copy Oil on canvas, $46 \times 33 \mathrm{~cm}$ gouache on canvas, $90 \times 71 \mathrm{~cm}$

\subsection{Influenced by African art}

The Cubists believed that the traditions of Western art had become exhausted and another remedy they applied to revitalize their work was to draw on the expressive energy of art from other cultures, especially African art. However, they were not interested in the true religious or social symbolism of these cultural objects, but valued them superficially for their expressive style. They viewed them as subversive elements that could be used to attack and subsequently refresh the tired tradition of Western art. [6]

\subsubsection{What is African art}

African art is the result of talent African since ancient times, that his goal was provided requirements to the African's community, and it handed down by generations who contributed to have been distinctive and characteristics made it one of the art worlds, and has the aesthetic impact.

\subsubsection{African artworks features}

1) African impact of his community traditions and provided requirements of the society.

2) African used raw materials available in his environment such as wicker, wood, metals, stones, ivory and others.

3) African interested of masks and statues, also influenced by their religious beliefs,

4) African artworks achieved the compatibility with the environment.

5) African exceeded at sculpture and wooden artwork using unique symbolic elements.

6) African art characterized by spontaneity, simplicity, originality and innocence, with aesthetic and spiritual effects.

7) Moreover, African draws on a rich variety of day to day scenes. Through a combination of direct words and image conveys his vision of African life as he experienced it. 
Some works are simple and static, others have the more complex and dynamic message.[11] Example: fig. 14

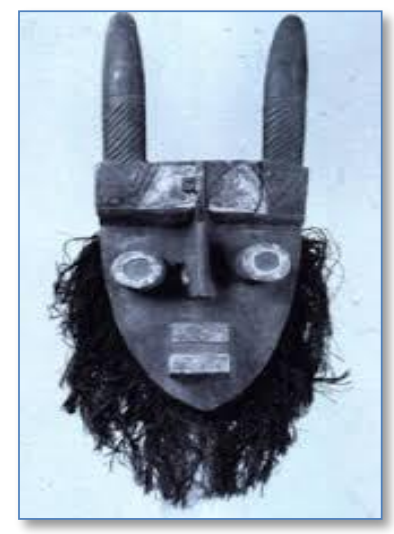

Fig. 14: African Grebo Mask Bought by Pablo Picasso in 1912 Musée Picasso, Paris.
Picasso shows that his understanding of African sculpture is from the point of view of its non-natural or conceptual aspect. This mask from the Ivory Coast in West Africa, shows that it has been constructed out of separate pieces of wood and hair, not modeled or carved as traditional Western European sculpture would be, the face is flat. The eyes are two-round cylinder. The nose is a triangle the mouth is a cube and conveys. It shows powerful but not naturalistic. [12]

It is widely acknowledged that these constructions changed the course of modern sculpture. Picasso broke the rules by using found materials to make individual elements, each with their own identifiable form. This construction technique allowed Picasso to create open planes, which would have been much more difficult if sculpting from a solid mass. Until this time, sculpture was largely figurative, but perhaps more significantly it was expected to look 'finished', a demonstration of an artist's technical skill. [13]

\subsection{Picasso's paintings description $\&$ analysis refer to:} tab. 3

Table 3: Picasso's Paintings Description \& Analysis

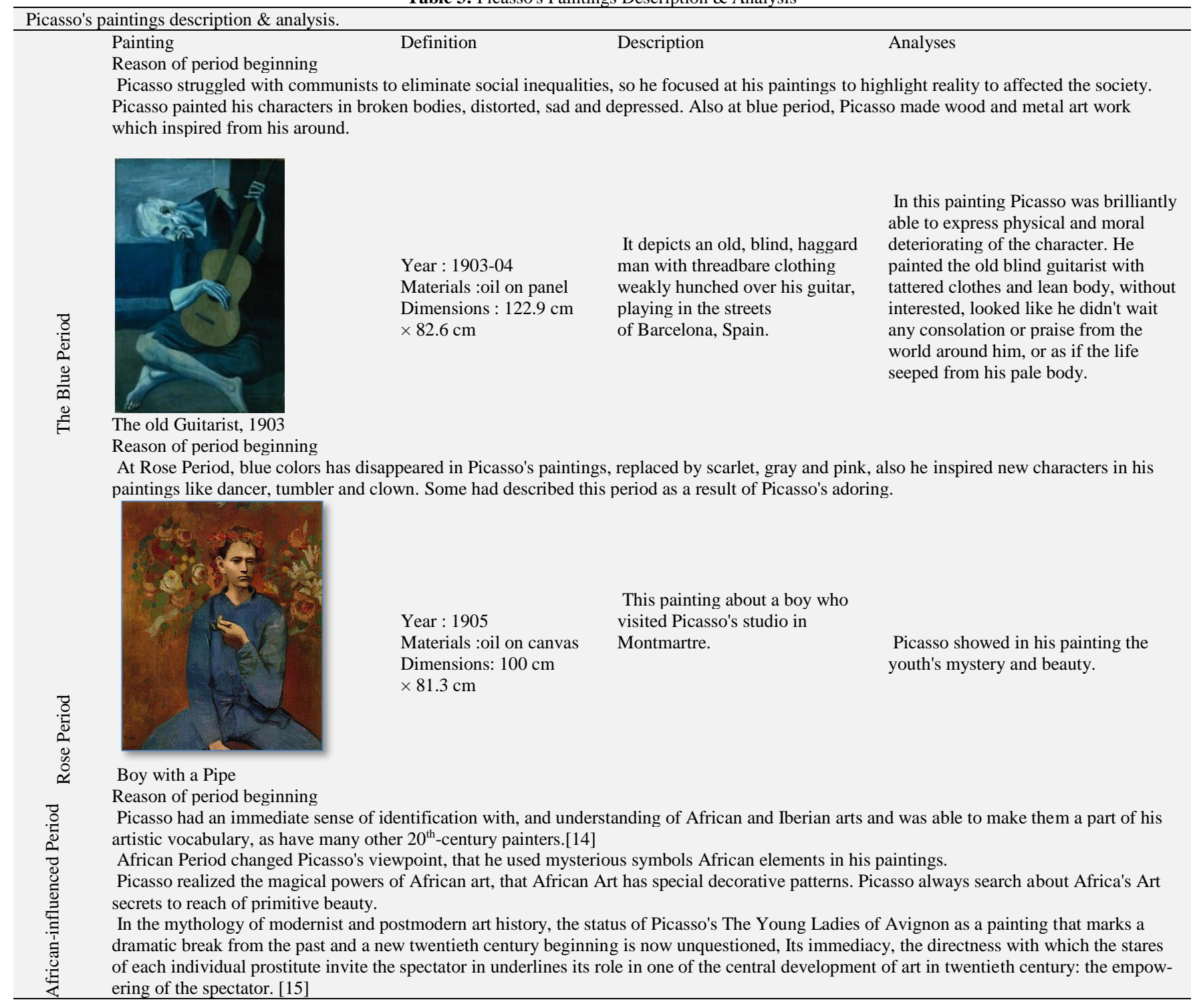




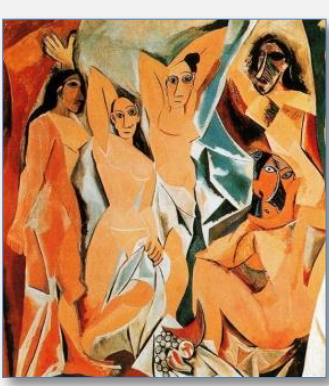

Year : 1907

Materials :oil on canvas Dimensions: $233.7 \mathrm{~cm}$ $\times 243.9 \mathrm{~cm}$

Location: Museum of Modern Art, New York City.
The work portrays five nude female prostitutes from a brothel on Carrer d'Avinyó (Avinyó Street) in Barcelona. Each figure is depicted in a disconcerting confrontational manner and none are conventionally feminine.

Three figures on the left exhibit facial features in

the Iberian style of Picasso's native Spain, while the two on the right are shown with African mask-like features.

[16]
Picasso didn't draw the natural views, but he preferred to shown women profiles expressions.
The Young Ladies of Avignon

Reason of period beginning In the latter years of his life, Picasso sought solace from his celebrity, marrying Jacqueline Rogue in 1961. His later paintings were heavily portrait-based and their palettes nearly garish in hue. Critics have generally considered them inferior to his earlier work, though in recent years they have been more enthusiastically received. He also created many ceramic and bronze sculptures during this later period.
Year : 1967

Materials: steel. Dimensions: $15 \mathrm{~m}-$ high Location: Chicago
It could be a bird, a horse, a woman or a totally abstract shape. The sculpture, one of the most recognizable landmarks in downtown Chicago.
Picasso's artwork draws on all his artistic experience over the years, with its distortion of form, the basketwork structure connecting the minimalis facial contours with the huge steel wing-like structures for the hair.

\section{Cubism ideology applications}

\subsection{Search overall layout}

- As discussed in previous review, these are the search results:

1) From previous Picasso's works analysis; we conclude that, he uses Cubic basic characteristics at his artworks by drawing faces in both front and side only.

2) Many of his works were influenced by African art.

3) He emphasized the two-dimensional scene of the painting by avoiding everything that gives a deep sense of emptiness.

4) Intentionally fragmentation of the space to achieve the idea of chaos (organized chaos).

5) Use the symbol to explain his idea.
6) Use sharp lines, usually straight, which remind us of broken glass.

7) The spread movement in different directions is in most of its works.

8) Design has aesthetic characteristics that effect positively at user.

\subsection{Proposal designs}

The search aims to create a relationship between art theories and interior design, to can be exploring new trends of design. To achieve search objectives, using Picasso \& Cubic basic characteristics in interior and furniture design in next proposals. Refer to: tab. 4

Table 4: Proposal Design

Using Picasso \& Cubic basic characteristics in interior and furniture design.

\begin{tabular}{llll}
\hline Design and color & \multicolumn{2}{l}{ Cubism ideology } & \\
inspired by Picasso & \multicolumn{2}{l}{ Design configurations achieved analytical results. } \\
& $\begin{array}{lll}\text { Influenced by Afri- } \\
\text { can art }\end{array}$ & Chaos & Spread movement \\
& Result (2) & Result(4) & Result(6) \\
& Interior Design & &
\end{tabular}

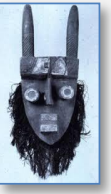

concept inspired by African Art period.
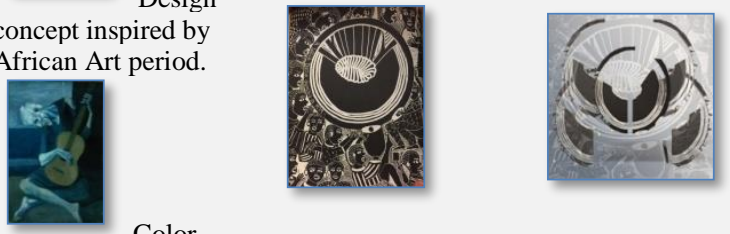

Colo inspired by blue period.

Design configurations

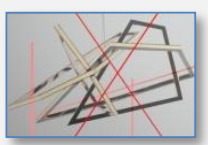

Horizontal spread movement to form walls.

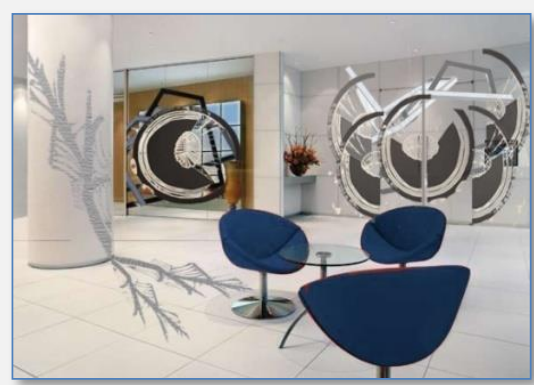

Proposal design (1)

Arts gallery design - Main hall. 


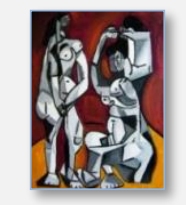

Form inspired

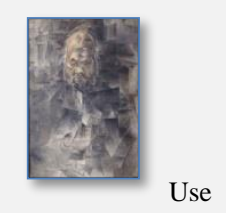

cube in painting techniques.

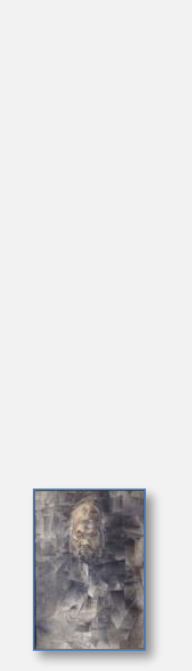

Use cube in painting techniques.
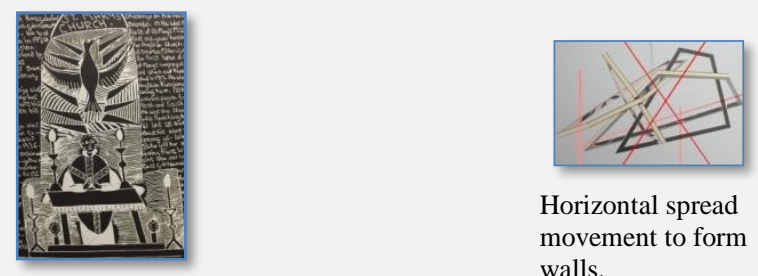

Horizontal spread movement to form walls.

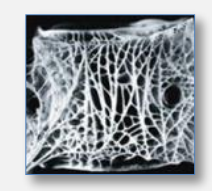

Interlaced carved lines

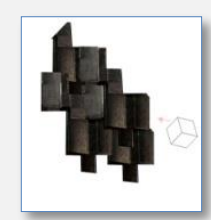

Using cube in design form.

Furniture Design

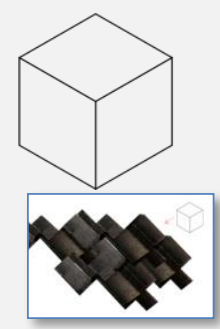

Using cube in design form.

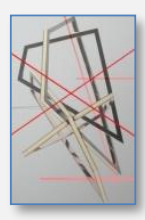

Vertical spread movement to form the back.

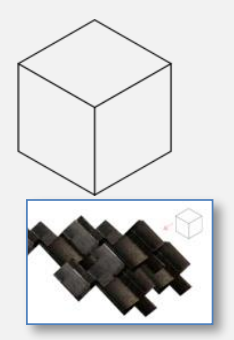

Using cube in design form.

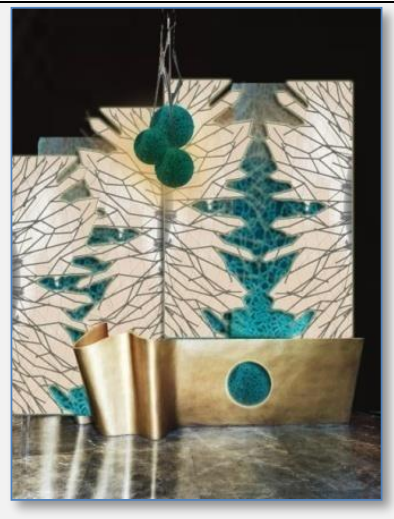

Proposal design (2)

Arts gallery design - Reception desk

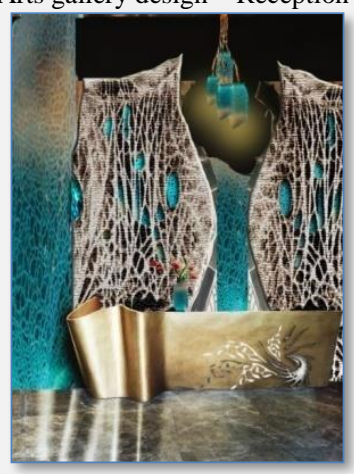

Proposal design (4)-Arts gallery design - Reception desk

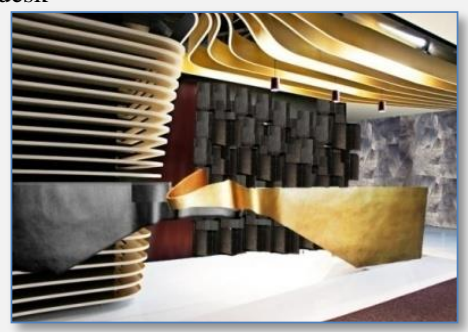

Redesign (5)-Arts gallery design - Main hall.

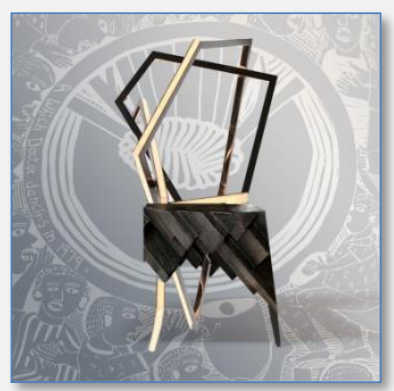

Proposal design (1) - Chair

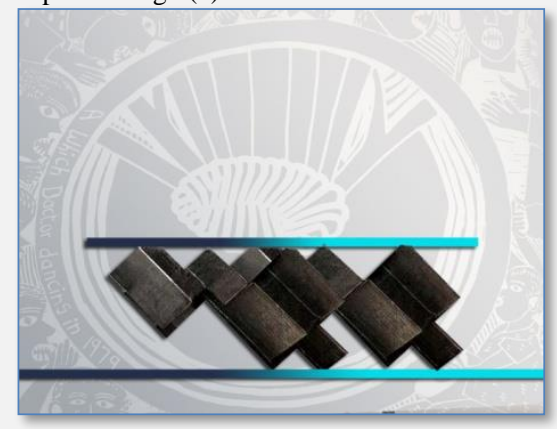

Proposal design (2) Coffee table 


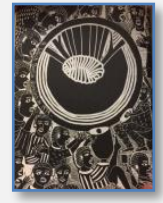

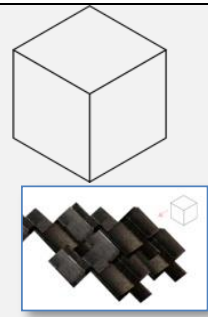

Using cube in design form.

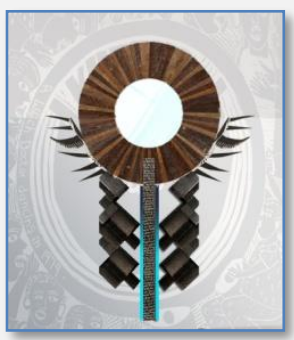

Proposal design (3) - Mirror unite

\section{Conclusion}

The mainly purpose of this research was to determine that philosophy analysis behind famous painters improves designer's creation. In addition, studying aesthetic concepts in light of the interrelationship between art and interior design, that can explore new trends of design. The search concluded that Cubism was such a big step in modern design, and we can really see the difference between other's styles and this one, that was the first abstract style of modern art. Moreover, Cubism continues to inspire the work of many contemporary artists, which still use the stylistic and theoretical features of this style. Picasso was able to reflect the visual experiences into abstract symbols, through cubism structural forming. Finely, combination deferent art styles raise design and furniture's aesthetic aspect.

\section{References}

[1] Art Humanities Primary Source Reading 49. Retrieved March 14,2017, from http://www.learn.columbia.edu

[2] C. Harrison and P. Wood, Art in Theory, Blackwell, 1949. P211

[3] Influence-art-history-cubism. Retrieved February 25,2017, from https://www.pixel77.com

[4] Learning/themes/cubism. Retrieved February 22,2017, from https://www.moma.org

[5] J. W Nixon, De Stijl; Ccea Gce History of Art, 2004

[6] Cubism - The First Style of Abstract Art, Retrieved February 28,2017, from http://www.artyfactory.com

[7] Pablo Picasso Biography. Retrieved February 20, 2017, from http://www.biography.com

[8] Pablo Picasso. Retrieved February 22,2017 , from www.TheArtStory.org

[9] H. Hady, The effect of African art on Picasso's paintings, Human Sciences Journal, Babylon University, 2015.

[10] Paul Cézanne and Pablo Picasso. Retrieved February 20,2017, from http://www.pablopicasso.org

[11] O. Levinson, The African Dream, foreword by Nelson Mandela, Thames and Hudson,1992, p32

[12] M. Acton, learning to look at Modern Art, Routledge, New Fetter Lane, London, 2004. P14

[13] J. Heuman, A Technical Study of Picasso's Construction Still Life 1914, Tate Papers Issue, 11/2009. P2

[14] Unnamed, the book of art, How to look at art origins of Western art Italian art to 1800, Grolier Incorporated, New York, 1976. P14

[15] C. Green, Picasso's (Les Demoiselles d'Avignon), Cambridge University Press, UK, 2001.p(2)

[16] Demoiselles_d'Avignon. Retrieved February 20, 2017, from https://en.wikipedia.org. 